\title{
UJI EFEKTIVITAS EKSTRAK ETANOL BUAH PARE (Momordica charantia L.) SEBAGAI ANTIBAKTERI Salmonella typhi
}

\author{
Oom Komala ${ }^{1}$, Bina Lohita Sari ${ }^{2}$, Nina Sakinah ${ }^{3}$ \\ 1) Program Studi Biologi FMIPA UNPAK - Bogor \\ 2,3) Program Studi Farmasi FMIPA UNPAK - Bogor \\ Email :komalaoom20@yahoo.co.id
}

\begin{abstract}
ABSTRAK
Penelitian yang bertujuan untuk mengetahui efektivitas antibakteri dari beberapa konsentrasi ekstrak etanol buah pare terhadap bakteri Salmonella typhi telah dilakukan. Pengujian antibakteri ekstrak etanol buah pare dilakukan dengan mengukur Diameter Daerah Hambat (DDH) melalui metode difusi kertas cakram dan Konsentrasi Hambat Minimum (KHM) melalui metode dilusi agar padat. Pengujian DDH dilakukan terhadap konsentrasi ekstrak buah pare 12,5\%, 25\%, 50\%, 75\%, serta kloramfenikol 30 UI sebagai kontrol positif dan aquadest sebagai kontrol negatif. Sedangkan pengujian KHM dilakukan terhadap konsentrasi 10\%, 20\%, 30\%, 40\%, 50\%, 60\%, 70\% dan 80\%. Hasil penelitian menunjukkan bahwa ekstrak etanol buah pare kurang efektif sebagai antibakteri terhadap Salmonella typhi, karena pada pengujian DDH zona hambat yang terbentuk tidak absolut. KHM berada pada konsentrasi $60 \%$, dimana tidak ada pertumbuhan bakteri.
\end{abstract}

Kata kunci: Buah pare, Salmonella typhi, efektivitas antibakteri

\section{ABSTRACT}

The study aims to determine the antibacterial effectiveness from several concentrations of bitter melon fruit against Salmonella typhi had be done. Antibacterial testing is measured by Diameter of Inhibitory Region (DIR) through paper disc diffusion method and Minimum Inhibitory Concentration (MIC) through the dilution method to be solid. DIR Tests carried out on extract concentration bitter melon fruit $12.5 \%, 25 \%$, $50 \%, 75 \%$, and chloramphenicol $30 \mathrm{UI}$ as a positive control and distilled water as a negative control. Meanwhile, MIC testing performed on the concentration of 10\%, 20\%, $30 \%, 40 \%, 50 \%, 60 \%, 70 \%$ and $80 \%$. The results showed that ethanol extract of bitter melon fruit is less effective as an antibacterial against Salmonella typhi, because in testing DIR inhibitory zone formed is not absolute. However, MIC can be concluded at a concentration of $60 \%$, because it was no bacterial growth .

Key words: Momordica charantia L., Salmonella typhi, antibacterial effectiveness

\section{PENDAHULUAN}

Buah pare (Momordica charantia L.) merupakan salah satu tanaman yang mengandung senyawa-senyawa yang berkhasiat dalam pengobatan seperti alkaloid, saponin, flavonoid, triterpenoid, dan asam momordica (Cahyadi, 2009). Di Indonesia tanaman pare (Momordica charantia L) selama ini dikenal sebagai sayur-sayuran yang dikonsumsi sehari-hari. Sejalan dengan perkembangan ilmu pengetahuan dan teknologi, masyarakat ingin memanfaatkan tanaman pare sebagai hasil alam untuk dikembangkan sebagai tanaman obat yang mempunyai nilai ekonomi tinggi. Menurut Subahar (2004) buah pare berkhasiat sebagai obat untuk demam, disentri, kencing manis, dan 
radang tenggorokan. Khasiat buah pare dalam menanggulangi penyakit tifus belum banyak penelitian.

Salah satu bakteri penyebab tifus adalah Salmonella typhi. Infeksi oleh bakteri ini terjadi dari memakan makanan yang terkontaminasi dengan feses yang mengandung bakteri Salmonella typhi dari organisme pembawa (hosts). Setelah masuk dalam saluran pencernaan maka bakteri ini akan menyerang dinding usus yang menyebabkan kerusakan dan peradangan. (Jawetz dan Adelbeg's, 2004).

Penelitian ini bertujuan untuk mempelajari efektivitas ekstrak buah pare (Momordica charantia L.) sebagai antibakteri Salmonella typhi.

\section{BAHAN DAN METODE PENELITIAN}

Buah pare (Momordica charantia L.) yang berumur sedang ( \pm 3 bulan) dikeringkan selanjutnya digiling dan diayak menggunakan mesh 20. Karakterisasi serbuk buah pare dilakukan terhadap kadar air (tidak lebih dari 10\%, Depkes RI, 1985), dan kadar abu (tidak lebih dari 10,5\%, DepkesRI, 1995). Serbuk simplisia yang didapat selanjutnya diekstrak menggunakan metode maserasi.

Maserasi dilakukan dengan cara merendam serbuk buah pare dalam pelarut etanol $70 \%$ sebanyak 7,5 1 selama 24 jam, lalu disaring dengan kain saring dan direndam kembali dalam etanol $70 \%$ sisanya sebanyak 2,5 1 sampai terekstraksi. Setelah itu diuapkan dengan alat rotavapour, pelarut alkohol yang masih tersisa diuapkan pada water bath serta diangin-anginkan sehingga didapatkan ekstrak yang kental. Rendemen yang diperoleh dihitung dengan membandingkan berat ekstrak yang diperoleh dengan berat awal simplisia dikalikan $100 \%$.

Ekstrak yang diperoleh selanjutnya diuji secara kualitatif kandungan senyawa alkaloid (menggunakan pereaksi Mayer dan Bouchardat) flavonoid (Depkes RI, 1995), saponin (Depkes RI, 1977), dan triterpenoid (Uji Lieberman-Buchard).
Pembuatan media agar dilakukan sebagai berikut sebanyak 38 gram serbuk media Mueller Hinton dilarutkan dalam 1 liter aquadest. Setelah homogen dilakukan . sterilisasi dengan autoklaf pada suhu $121^{\circ} \mathrm{C}$ selama 15 menit, setelah itu dituangkan dekat api bunsen kedalam cawan petri sebanyak $20 \mathrm{~mL}$.

Bakteri yang sudah diencerkan konsentrasi $10^{6} / \mathrm{ml}$. dituangkan sebanyak 1 $\mathrm{ml}$ kedalam media hangat. Setelah homogen kemudian kertas cakram yang mengandung ekstrak buah pare dengan konsentrasi $12,5 \%, 25 \%, 50 \%$, $75 \%$; dan. kontrol positif (kloramfenikol) konsentrasi 30 UI, di tempelkan di permukaan media agar dalam cawan petri (metode difusi kertas cakram) (Alcamo, 1991). Cawan petri tersebut diinkubasi dalam inkubator selama 24 jam pada suhu $37^{\circ} \mathrm{C}$. Daerah bening disekitar kertas cakram ekstrak buah pare dan kloramfenikol diukur. Pengujian dilakukan sebanyak 4 kali pengulangan.

Penentuan Konsentrasi Hambat Minimum (KHM) dilakukan menggunakan metode dilusi padat. Larutan uji dibuat dengan mengencerkan secara serial dengan konsentrasi $10 \%, 20 \%, 30 \%, 40 \%, 50 \%$, $60 \%, 70 \%$ dan $80 \%$. Sebanyak $1 \mathrm{ml}$ larutan uji dimasukan ke dalam cawan petri steril yang berisi $9 \mathrm{ml}$ media Mueller Hinton hangat dengan suhu $40^{\circ}-50^{\circ} \mathrm{C}$, tuangkan $1 \mathrm{ml}$ suspensi bakteri uji konsentrasi $10^{6} / \mathrm{ml}$, campur homogen. Inkubasi pada suhu $37^{\circ} \mathrm{C}$ selama 24 jam. KHM ditentukan pada cawan konsentrasi ekstrak terendah yang tidak ditumbuhi bakteri (Alcamo, 1991).

\section{HASIL DAN PEMBAHASAN Hasil Analisis Karakteristik Simplisia}

Penetapan kadar air dan kadar abu simplisia buah pare perlu dilakukan sebelum melakukan ekstraksi dengan tujuan untuk memberikan batasan minimal atau rentang besarnya kandungan air dan kadar abu dalam suatu bahan (Depkes RI, 
2000). Hasil penetapan kadar air simplisia buah pare diperoleh sebesar $6,88 \%$. Hasil tersebut memenuhi standar kadar air simplisia buah yang diperbolehkan yaitu $\leq$ 10\% (Depkes RI, 1985). Semakin kecil kandungan air dalam suatu simplisia, maka akan sangat berguna untuk memperpanjang daya tahan serbuk simplisia selama penyimpanan. Sedangkan hasil penetapan kadar abu simpisia buah pare diperoleh sebesar 10,9\%. Hasil tersebut belum memenuhi karena sedikit melebihi ketentuan kadar abu buah pare dalam Depkes RI (1997) yaitu tidak lebih dari 10,5\%. Penetapan kadar abu simplisia dilakukan untuk memberikan gambaran kandungan senyawa anorganik yang terkandung dalam simplisia, baik yang berasal dari tanaman secara alami maupun kontaminan selama proses pembuatan simplisia.

\section{Hasil Pembuatan Ekstrak}

Hasil ekstraksi ditentukan rendemen, penentuan rendemen bertujuan untuk mengetahui perbandingan dari simplisia dan ekstrak, dari penentuan rendemen dapat diketahui jumlah ekstrak dari simplisia pada berat tertentu (Depkes RI, 2000). Rendemen yang diperoleh sebesar 21,156\%, Berdasarkan perhitungan rendemen ekstrak buah pare menunjukkan bahwa rendemen buah pare memenuhi syarat yaitu tidak kurang dari 17,9\% (Depkes RI, 2006).

\section{Hasil Penetapan Kadar Abu Total Ekstrak}

Unsur mineral dikenal juga sebagai zat organik atau kadar abu. Dalam proses pembakaran, bahan-bahan organik terbakar tetapi zat anorganiknya tidak, karena itulah disebut abu. Banyak dari mineral telah jelas diketahui fungsinya pada makanan ternak, namun belum banyak penelitian sejenis dilakukan pada manusia. Penetapan kadar abu total ekstrak dilakukan untuk melihat cemaran berupa bahan anorganik pada ekstrak yang sukar menguap walaupun dipanaskan pada suhu tinggi.

Pada penelitian ini kadar abu total ekstrak buah pare sebesar 7,69\%, nilai ini belum memenuhi karena sedikit melebihi ketentuan kadar abu buah pare dalam Depkes (1997) yaitu 7,2\%. Hal ini mungkin masih terdapat kotoran atau debu yang tidak tercuci.

\section{Hasil Penetapan Kadar Air Ekstrak}

Penetapan kadar air simplisia dilakukan untuk mengetahui terpenuhinya ketentuan kadar air ekstrak dengan mutu yang baik. Kadar air harus ditentukan karena air yang tersisa dalam ekstrak pada kadar air tertentu merupakan media pertumbuhan kapang dan jasad renik. Pertumbuhan kapang dan mikroorganisme lain dapat menyebabkan perubahan kimia pada senyawa aktif dan dapat mengakibatkan kemunduran mutu ekstrak.

Pada penelitian ini kadar air ekstrak buah pare sebesar 6,03\%, nilai ini menujukkan bahwa ekstrak yang digunakan memenuhi ketentuan ekstrak kental ( $\leq 10 \%)$ (Depkes, 2000) .

\section{Hasil Uji Fitokimia}

Hasil uji fitokimia menunjukkan bahwa buah pare memberikan hasil positif pada uji alkaloid dan saponin, namun memberikan hasil negatif pada uji flavonoid dan triterpenoid (Tabel 1).

Tabel 1. Hasil Pengamatan Senyawa

\begin{tabular}{|c|c|c|}
\hline Gol. senyawa & Data Pengamatan & $\begin{array}{l}\text { Hasil } \\
\text { Analisis }\end{array}$ \\
\hline \multicolumn{3}{|l|}{ Alkaloid } \\
\hline Bouchardat & Endapan coklat & + \\
\hline Mayer & Endapan putih & + \\
\hline Flavonoid & Warna coklat kehitaman & - \\
\hline Saponin & Timbul Buih & + \\
\hline \multicolumn{3}{|l|}{ Triterpenoid } \\
\hline Anhidrat Asetat & Larutan tidak berwarna & - \\
\hline Asam Sulfat & Larutan tidak berwarna & - \\
\hline
\end{tabular}




\section{Pengujian Antibakteri Ekstrak Etanol Buah Pare Terhadap Bakeri Salmonella typhi}

\section{Diameter Daerah Hambat}

Pengujian antibakteri dilakukan untuk melihat ekstrak yang mempunyai efektivitas paling efektif sebagai antibakteri Salmonella typhi. Pengujian antibakteri menggunakan difusi kertas cakram, yang merupakan metode paling banyak digunakan karena lebih sensitif terhadap senyawa-senyawa antibakteri baru yang belum diketahui aktivitasnya. Pada metode ini penghambatan pertumbuhan ditujukan oleh luasnya wilayah jernih (zona hambat) di sekitar kertas cakram (Brander et al., 1999).

Dari hasil pengamatan dan pengukuran diameter zona hambat yang berupa zona bening di sekitar kertas cakram (Gambar 1) menunjukkan bahwa ekstrak etanol buah pare pada konsentrasi berbeda mempunyai tingkatan efektivitas antibakteri yang berbeda-beda terhadap bakteri Salmonella typhi.

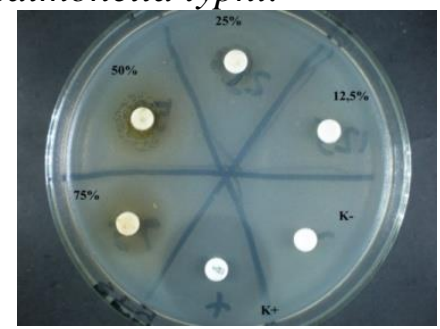

Gambar 1. Hasil Uji Diameter Daya Hambat Ekstrak Buah Pare Terhadap Bakteri Salmonella typhi.

Keterangan : K+ : Kontrol positif, K-:Kontrol negatif, Ekstrak buah pare 12,5\%,25\%,50\%, dan $75 \%$.

Berdasarkan pengujian terhadap bakteri Salmonella typhi, daerah hambat ekstrak etanol buah pare pada konsentrasi $12,5 \% ; 25 \% ; 50 \%$ dan $75 \%$ memiliki lebar daerah hambat lebih rendah bila dibandingkan dengan kontrol positif yaitu Kloramfenikol 30 UI. Zona hambat yang dihasilkan oleh ekstrak buah pare berturutturut rata-rata diameter sebesar $6,5 \mathrm{~mm}$, $12,4 \mathrm{~mm}, 16,3 \mathrm{~mm}, 17,2 \mathrm{~mm}$ lebih kecil dari diameter kloramfenikol 30,19 $\mathrm{mm}$ (Gambar 1). Hal ini menunjukkan efektivitas buah pare terhadap bakteri Salmonella typhi tidak kuat atau lemah. Sehingga zona hambat di sekitar kertas cakram menjadi tidak rata, masih terlihat pertumbuhan bakteri Salmonella typhi yang ditandai dengan terbentuknya koloni-koloni bakteri di dalam zona hambat (Parsial).

Tabel 2. Diameter Daerah Hambat ekstrak

\begin{tabular}{cccccc}
\hline \multirow{2}{*}{ Ulangan } & \multicolumn{5}{c}{ Diameter Daerah Hambat (mm) } \\
& K1 & K2 & K3 & K4 & K+ \\
\hline 1 & 14,25 & 13 & 14,25 & 18,35 & 30 \\
2 & 11,75 & 12,45 & 17,25 & 18 & 30 \\
3 & 0 & 10,75 & 17 & 18,75 & 30,75 \\
4 & 0 & 13,5 & 12 & 13,75 & 30 \\
Jumlah & 26 & 49,7 & 65,5 & 68,85 & 12,75 \\
Rata-rata & 6,50 & 12,43 & 16,38 & 17,21 & 30,19 \\
\hline
\end{tabular}

kental buah pare terhadap bakteri Salmonella typhi

Berdasarkan Tabel 2 di atas menunjukkan bahwa ekstrak kental buah pare pada, konsentrasi $75 \%$ paling efektif diantara konsentrasi ekstrak lainnya, karena memiliki diameter daerah hambat yang paling besar dengan rata-rata diameter daerah hambat sebesar 17,21 mm. Namun bila dibandingkan dengan kontrol positif yaitu kloramfenikol, maka ekstrak etanol buah pare memiliki efektivitas antibakteri sangat lemah. Menurut Setiabudi (1987) kloramfenikol bersifat bakteriostatik yang bekerja menghambat enzim peptidil transferase pada proses sintesis protein kuman. Lemahnya efektivitas buah pare ini kemungkinan terjadi karena kandungan fitokimianya yang hanya mengandung senyawa alkaloid dan saponin, sehingga kurang kuat dalam menghambat bakteri Salmonella typhi. Nilai diameter daerah hambat yang diperoleh, di analisis menggunakan Rancangan Acak Lengkap (RAL). Dengan perlakuan yang digunakan adalah konsentrasi sedangkan responnya adalah 
diameter daerah hambat (DDH) yang terbentuk. Pengujian ini dilakukan dengan 4 kali ulangan. Berdasarkan analisis ragam terhadap bakteri Salmonella typhi memperlihatkan bahwa nilai diameter daerah hambat dari ke enam perlakuan menunjukkan perbedaan yang nyata dengan $\mathrm{P}<0,01$. Hasil uji Duncan menunjukkan bahwa nilai DDH dari ke enam perlakuan menunjukkan perbedaan yang nyata.

\section{Pengujian Konsentrasi Hambat Minimum (KHM)}

Pada Pengujian Konsentrasi Hambat Minimum (KHM) metode yang digunakan adalah metode dilusi padat.

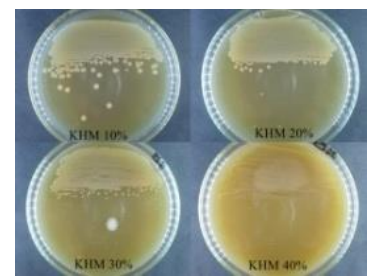

a

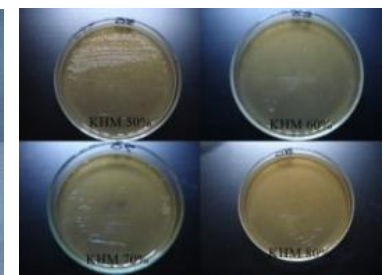

b
Gambar 2. Hasil Uji Konsentrasi Hambat Minimum (KHM) Ekstrak Buah Pare Terhadap Bakteri Salmonella typhi

Keterangan KHM 10\%, 20\%, 30\%,40\% (a) dan $50 \%, 60 \%, 70 \%, 80 \%$ (b).

Hasil yang diperoleh menunjukkan ekstrak etanol buah pare pada konsentrasi $10 \%$ hingga konsentrasi 30\% masih menunjukkan adanya pertumbuhan bakteri yang sempurna seperti pertumbuhan bakteri pada kontrol negatif.. Pada konsentrasi $40 \%$ hingga konsentrasi $50 \%$ ekstrak etanol buah pare menunjukkan daya hambatnya ditandai dengan pertumbuhan bakteri yang lebih jarang dibandingkan dengan kontrol negatif, hal ini menunjukkan bahwa konsentrasi ekstrak etanol buah pare tersebut memiliki sifat bakteriostatik yaitu dapat menghambat pertumbuhan bakteri. Pada konsentrasi $60 \%$ hingga konsentrasi $80 \%$ ekstrak etanol buah pare menunjukkan daya hambat yang cukup besar ditandai tidak adanya pertumbuhan bakteri pada konsentrasi tersebut, hal ini menunjukkan bahwa ekstrak etanol buah pare pada konsentrasi tersebut memiliki sifat bakteriosidal "Complete Bactericidal". sehingga dapat disimpulkan KHM berada di konsentrasi 60\% (Gambar 2).

\section{SIMPULAN DAN SARAN}

\section{Simpulan}

1. Ekstrak etanol buah pare (Momordica charantia L) menunjukkan efektivitas pada konsentrasi $75 \%$, namun lemah dalam menghambat pertumbuhan bakteri Salmonella typhi, karena masih terbentuk koloni-koloni bakteri di dalam zona hambat (Parsial).

2. Pada pengujian konsentrasi hambat minimum disimpulkan KHM berada di konsentrasi $60 \%$.

3. Senyawa yang teridentifikasi dari ekstrak etanol buah pare (Momordica charantia L) adalah alkaloid dan saponin.

\section{Saran}

1. Perlunya pengujian lebih lanjut mengenai pelarut yang cocok untuk meserasi atau metode lainnya agar senyawa aktif yang terkandung dalam buah pare dapat terisolasi secara maksimal sehingga efektivitas antibakterinya dapat maksimal pula.

2. Perlunya pengujian lebih lanjut mengenai isolasi senyawa apa saja yang terkandung dalam buah pare guna mengetahui senyawa yang lebih efektif sebagai antibakteri selain alkaloid dan saponin.

\section{DAFTAR PUSTAKA}

Alcamo, I.E.1991. Fundamentals of Microbiology. Third Edition. The Benyamin Cummings Publishing Company. State University of New York.

Brander, G. C., Pough, D. M, Bywater, R. J and Jenkins, W. L. 1999. Veterinary Applied Pharmacology and Therapeutic. $5^{\text {th }}$ Edition. Brailler Tindal, London.

Cahyadi, R. 2009. Uji Toksisitas Akut Ekstrak Etanol Buah Pare 
(Momordica charantia L.) Terhadap Larva Artemia Salina Leach Dengan Metode Brine Shrimp Lethality Test (BSLT). Skripsi Program Pendidikan Sarjana Fakultas Kedokteran Universitas Diponegoro. Semarang.

Depkes RI. 1985. Cara Pembuatan Simplisia. Dirjen POM. Jakarta. . 1995. Materi Medika Indonesia. Jakarta
.1997. Informasi Simplisia Asing. Dirjen POM. Jakarta.

- . 2000. Parameter Standar Umum Ekstrak Tumbuhan Obat. Jakarta 2006. Parameter Standar Umum Ekstrak Tumbuhan Obat. Dirjen POM. Jakarta.

Jawetz, M. dan Adelbeg's. 2004. Mikrobiologi Kedokteran. Edisi 23. Jakarta: EGC. 171-661.

Setiabudi, R. 1987. Golongan Tetrasiklin dan Kloramfenikol. Farmakologi dan Terapi. Edisi ke 3. Fakultas Kedokteran UI. Jakarta. 